\title{
Cell-Cell Interaction in Erythropoiesis
}

\author{
ROLE OF HUMAN MONOCYTES
}

\author{
John J. Rinehart, Esmail D. Zanjani, Benet Nomdedeu, Bobby J. Gormus, \\ and Manuel E. Kaplan, Departments of Medicine and Physiology, Hematology \\ Division, University of Minnesota School of Medicine and Veterans \\ Administration Hospital, Minneapolis, Minnesota 55417
}

\begin{abstract}
A B S T R A C T Erythroid burst forming units (BFU-E) are proliferative cells present in peripheral blood and bone marrow which may be precursors of the erythroid colony forming cell found in the bone marrow. To examine the possible role of monocyte-macrophages in the modulation of erythropoiesis, the effect of monocytes on peripheral blood BFU-E proliferation in response to erythropoietin was investigated in the plasma clot culture system. Peripheral blood mononuclear cells from normal human donors were separated into four fractions. Fraction-I cells were obtained from the interface of Ficoll-Hypaque gradients (20-30\% monocytes; 60-80\% lymphocytes); fraction-II cells were fraction-I cells that were nonadherent to plastic (2-10\% monocytes; 90-98\% lymphocytes); fraction-III cells were obtained by incubation of fraction-II cells with carbonyl iron followed by Ficoll-Hypaque centrifugation ( $>99 \%$ lymphocytes); and fraction-IV cells represented the adherent population of fraction-II cells released from the plastic by lidocaine ( $>95 \%$ monocytes). When cells from these fractions were cultured in the presence of erythropoietin, the number of BFU-E-derived colonies was inversely proportional to the number of monocytes present $(r=-0.96, P<0.001)$. The suppressive effect of monocytes on BFU-E proliferation was confirmed by admixing autologous purified monocytes (fractionIV cells) with fraction-III cells. Monocyte concentrations of $\geq 20 \%$ completely suppressed BFU-E activity. Reduction in the number of plated BFU-E by monocyte dilution could not account for these findings: a $15 \%$ reduction in the number of fraction-III cells plated resulted in only a $15 \%$ reduction in colony formation. These results indicate that monocyte-macrophages may play a significant role in the regulation of erythropoiesis and be involved in the pathogenesis of the hypoproliferative anemias associated with infection and certain
\end{abstract}

\footnotetext{
Received for publication 5 December 1977 and in revised form 10 July 1978 .
}

neoplasia in which increased monocyte activity and monopoiesis also occur.

\section{INTRODUCTION}

It is generally accepted that erythropoietin $(E p)^{1}$ regulates mammalian erythropoiesis $(1,2)$. Several lines of evidence suggest that cell-cell interactions also play an important role in the production of erythrocytes. Lymphocyte effects on in vivo erythropoiesis have been observed in several animal systems. Goodman and Shinpock (3) showed that proliferation of parent marrow in irradiated hybrid mice was enhanced by concomitant injection of parental thymus-derived cells. The degree of this enhancement was related to the number of thymus-derived cells injected. A recent study (4) demonstrates that the ability of the genetically normal $(+/+)$ bone marrow or spleen cells to correct the macrocytic anemia of $\mathrm{W} / \mathrm{W}^{\mathrm{v}}$ mice may be thymus-derivedcell dependent: treatment of these donor cells with complement and anti-sera to the thymus-derived-cell antigen Thy 1.2 abolishes their effect. Petrov et al. (5) have shown that the transfer of lymphocytes together with allogeneic bone marrow cells into lethally irradiated recipient mice resulted in the inactivation of spleen colony forming units; this effect was not linked to the H-2 histocompatibility system (6). The availability of culture techniques for the study of proliferation and differentiation of erythropoietic precursors in vitro has provided additional support for the existence of regulatory processes involving cell-cell interaction in erythropoiesis. Thus, suppression of normal human bone marrow erythroid colony forming units (CFU-E) by peripheral blood lymphocytes from some patients with Diamond-Blackfan syndrome (7) and aplastic anemia has been described (8). Steinberg et al. have

\footnotetext{
${ }^{1}$ Abbreviations used in this paper: BFU-E, erythroid burst forming units; CFU-E, erythroid colony forming units; EC, erythroid colonies; Ep, erythropoietin; F, fraction.
} 
also described suppression of erythroid burst forming units (BFU-E) by circulating thymus-derived cells from patients with Diamond-Blackfan syndrome (9).

In a preliminary study of human peripheral blood erythroid precursors, we used the plasma clot culture system (10) and previously described cell separation techniques (11). As others have shown, we found a highly variable number of BFU-E $/ 10^{5}$ mononuclear cells from normal donors. We undertook a study of this variability and found that normal BFU-E proliferation was modulated by monocytes. When procedures conducive to the preservation of circulating monocytes were employed in the preparation of blood mononuclear cells, the proliferation and (or) differentiation of BFU-E was found to be inversely related to the number of monocytes present. Thus, BFU-E proliferation was completely inhibited in the presence of $>20 \%$ monocytes. Removal of monocytes resulted in marked enhancement of BFU-E proliferation. Addition of purified monocytes to monocyte-depleted mononuclear cells inhibited BFU-E proliferation.

\section{METHODS}

After informed consent was obtained, blood was drawn from normal human donors, heparinized, and separated by a modification of the isopycnic gradient technique previously described (11). Briefly, blood was diluted 1:1 with Seligman's balanced salt solution (Ficoll, Pharmacia Fine Chemicals, Piscataway, N. J.; Hypaque, Winthrop Laboratories, Sterling Drug Co., New York), (1.077 sp gr), and centrifuged at $400 \mathrm{~g}$ for $25 \mathrm{~min}$ at $15^{\circ} \mathrm{C}$. In specific experiments to be described, isopycnic gradient centrifugations were performed by varying the time and temperature and by using FicollPaque (Pharmacia Fine Chemicals) (1.077 sp gr) instead of Ficoll-Hypaque. Interface cells, designated as fraction (F)-I, were utilized in cultures or were further separated into three cell fractions (Fig. 1); F-I cells were adjusted to $1.5 \times 10^{6}$ monocytes $/ \mathrm{ml}$ of RPMI containing $20 \%$ autologous sera. The percentage of monocytes in each fraction was determined by latex phagocytosis, Sudan black positivity and morphology of Giemsa-stained cytocentrifuge preparation. The values obtained by these techniques correlated closely $( \pm 3 \%)$. 3-ml aliquots were placed into $60-\mathrm{mm}$ culture dishes which were incubated $1.0 \mathrm{~h}$ at $37^{\circ} \mathrm{C}$. Nonadherent cells, designated as F-II cells, were removed by washing culture dishes six times with Hanks' balanced salt solution, then centrifuged, and suspended in autologous plasma. Carbonyl iron $(25 \mathrm{mg} /$ $\mathrm{ml}$ ) was added, the mixture was rotated for $30 \mathrm{~min}$ at $37^{\circ} \mathrm{C}$, and then layered over Ficoll-Hypaque. After centrifugation at $400 \mathrm{~g}$ for $30 \mathrm{~min}$ at room temperature, the resultant interface cells were obtained and designated as F-III. F-I cells that had adhered to culture dishes were isolated as follows. After nonadherent cells (F-II) were removed by washing, 3.0 ml of Seligman's balanced salt solution containing $30 \mathrm{mM}$ lidocaine and $10 \%$ autologous sera were added to each culture dish and incubated for $15 \mathrm{~min}$ at room temperature. Adherent cells were detached by this treatment or were removed by gently streaming Seligman's balanced salt solution onto residual attached cells. These suspended (previously adherent) cells were then washed three times by centrifugation to remove lidocaine and were designated as F-IV.

The plasma clot system used in these studies to culture erythroid cells has been previously described $(10,12)$. Briefly,

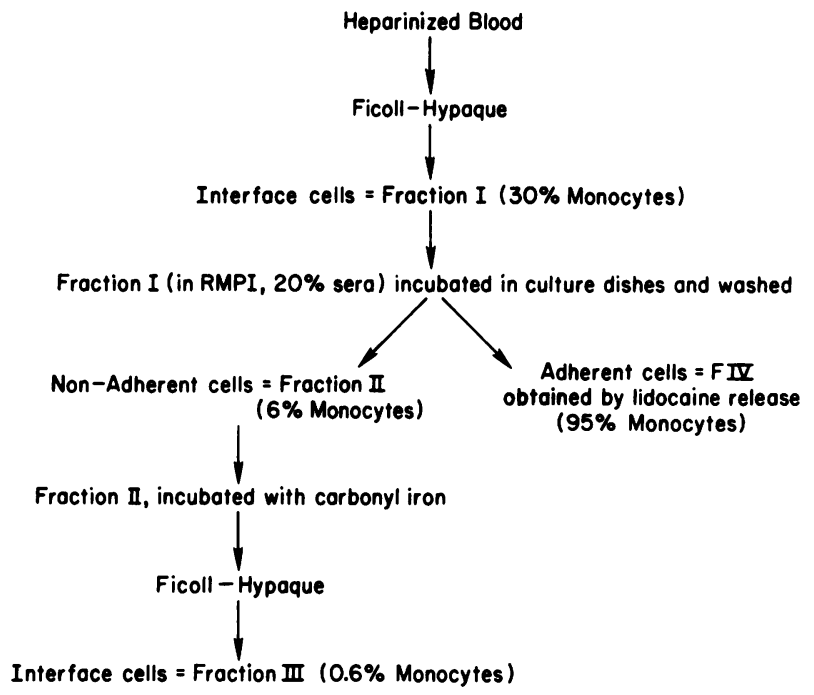

FIGURE 1 Schematic representation of cell separation. See text for details of the procedure.

cells were suspended to $0.5-4 \times 10^{6} / 1.1 \mathrm{ml}$ of media composed of $0.3 \mathrm{ml}$ fetal calf serum, $0.1 \mathrm{ml}$ bovine serum albumin (10\% in phosphate-buffered saline), $0.1 \mathrm{ml} \mathrm{L}$-asparigine (2 $\mathrm{mg} / \mathrm{ml}$ NCTC-109, Hyland Laboratories, Los Angeles, Calif.), $0.1 \mathrm{ml} \alpha$-thioglycerol (10 mM, NCTC-109), $0.1 \mathrm{ml}$ citrated bovine plasma, and contained $0.5,1,2,4$, or $6 \mathrm{U}$ of Ep. For each experimental point eight $0.1-\mathrm{ml} /$ well cultures were established and incubated at $37^{\circ} \mathrm{C}$ in humidified air with $5 \% \mathrm{CO}_{2}$ for 14 days. Clots were then removed, placed on glass slides,fixed with glutaraldehyde, and stained with benzidine.

Ep was assayed as follows. Female CF-1 mice were made polycythemic by exposure to 0.4 atmosphere barometric pressure $19 \mathrm{~h} /$ day for a total of $219 \mathrm{~h}$. Animals were then injected i.p. with different volumes of media (adjusted to $1 \mathrm{ml}$ with saline) to be assayed for Ep or with standard quantities of Ep on days 5 and 6 posthypoxia. Radioiron $(0.5 \mu \mathrm{Ci} /$ mouse $)$ was given i.v. on day 7 and the percent erythrocyte- ${ }^{59} \mathrm{Fe}$ uptake was determined on day 9. 6-10 mice were used to test each sample and standard; the units of $\mathrm{Ep}$ in each sample were determined from a standard curve as previously described (13).

Materials for these experiments were obtained as follows: Ficoll 400, Dextran 200, and Ficoll-Paque, Pharmacia Fine Chemicals; Hypaque (50\%), Winthrop Laboratories, Sterling Drug Co.; 60-mm tissue culture dishes, Falcon Plastics, Div. of BioQuest, Oxnard, Calif.; Hanks' balanced salt solution and fetal calf serum, Gibco, Grand Island, N. Y.; RPMI 1640, Associated Biomedic Systems, Inc., Buffalo, N. Y.; L-asparigine and bovine serum albumin, Calbiochem, San Diego, Calif.; citrated bovine plasma, Colorado Serum Co., Denver, Colo.; NCTC-109, Microbiological Associates, Walkersville, Md.; thrombin (bovine), Parke, Davis \& Co., Detroit, Mich.; $\alpha-$ thioglycerol, Aldrich Chemical Co., Milwaukee, Wis.; lidocaine $(40 \mathrm{mg} / \mathrm{ml})$, Astra Pharmaceutical Products, Inc., Worcester, Mass.; carbonyl iron powder, GAF Corp., New York; erythropoietin was supplied by the National Institutes of Health, Blood Resources Divison.

\section{RESULTS}

In a preliminary study of human peripheral blood BFU-E, we used the cell separation technique origi- 
nally described by Boyum (11). Resultant cells from normal donors were cultured in the plasma clot system and, as previously reported (10), variable numbers of BFU-E $/ 10^{5}$ cells resulted (Table I). We suspected that this variability in BFU-E proliferation might be a result of monocyte contamination of the cultured mononuclear cells. To examine this possibility, we used a separation technique to preserve monocyte number and viability in the initial separation step. Subsequent steps specifically depleted this mononuclear preparation of monocytes (Fig. 1). This cell separation procedure resulted in a large number of monocytes in F-I and in progressively fewer monocytes in F-II, and -III (Table II). F-IV (adherent cells) consisted of 95\% monocytes which we have previously shown to be functionally equivalent to the unseparated monocytes in F-I (14). Table II also demonstrates the formation of BFU-E-derived colonies by these fractions in the presence of Ep.

The numbers of BFU-E were determined under $\times 10$ magnification and areas of erythroid activity forming a distinct grouping of benzidine-positive subunits were considered as a single BFU-E colony. Although not all such subunits exhibited benzidine positivity in every colony, generally $60-80 \%$ were stained with benzidine. In general, no difficulties in identifying such distinct areas of erythroid "burst" activity were experienced with concentrations of mononuclear cells up to $2 \times 10^{6}$ cells $/ 1.1 \mathrm{ml}$ of the culture. The determina-

TABLE I

Preliminary Study of Peripheral Blood BFU-E

\begin{tabular}{cc}
\hline Normal donors* & No. of BFU-E/10s cells $t$ \\
\hline 1 & 6 \\
2 & 7 \\
3 & 11 \\
4 & 9 \\
5 & 7 \\
6 & 12 \\
7 & 10 \\
8 & 4 \\
9 & 11 \\
10 & 8 \\
11 & 18 \\
12 & 9 \\
13 & 10 \\
14 & 6 \\
15 & 7
\end{tabular}

* Blood was diluted with Hanks' balanced salt solution, layered over Ficoll-Hypaque (specific gravity, 1.077), and centrifuged in glass tubes at $400 \mathrm{~g}$ for $30 \mathrm{~min}$ at $20^{\circ} \mathrm{C}$. Interface cells were washed in Hanks' balanced salt solution and then generally allowed to stand in glass tubes on ice $1 \mathrm{~h}$. Resultant cells were cultured in the plasma clot system with $4 \mathrm{U} \mathrm{Ep} / 2$ $\times 10^{6}$ cells at $2 \times 10^{5}$ cells $/ 0.1 \mathrm{ml}$ culture.

$\ddagger$ Mean $\pm \mathrm{SE}=9 \pm 0.8$.
TABLE II

Relationship between Cell Fractions, Percent Monocytes, and BFU-E-Derived Colonies in Plasma Clot Cultures

\begin{tabular}{lccc}
\hline \multirow{2}{*}{$\begin{array}{c}\text { Cell } \\
\text { fraction }\end{array}$} & & \multicolumn{2}{c}{ No. of BFU-E/10s cells* } \\
\cline { 3 - 4 } & Monocytes & No Ep & +4 IU Ept \\
\hline F-I & $30 \pm 3$ & & \\
F-II & $6 \pm 1$ & 0 & $1.1 \pm 0.5$ \\
F-III & $0.6 \pm 0.2$ & 0 & $10.9 \pm 2.5$ \\
F-IV & 95 & 0 & $20.7 \pm 2.9$ \\
\hline
\end{tabular}

* Each value represents the mean $\pm 1 \mathrm{SE}$ of nine separate studies.

\$ Ep used in these studies was collected and concentrated by the Department of Physiology, University of Northeast, Corrientes, Argentina, and further processed and assayed by the Hematology Research Laboratories, Children's Hospital of Los Angeles, Los Angeles, Calif., under grant HE-10880 from the National Heart, Lung, and Blood Institute of the National Institutes of Health.

tions of BFU-E colonies, however, were more difficult with starting cell concentrations of $3 \times 10^{6}$ cells $/ 1.1 \mathrm{ml}$ of culture medium and became almost impossible when $4 \times 10^{6}$ cells were used. In the latter case, the growth was confluent with no clear separation of areas of erythroid activity. When $2 \times 10^{5} \mathrm{~F}$-III cells/well were cultured with various amounts of $\mathrm{Ep}$, there was a linear increase in the number of erythroid colonies (EC) formed between 0.5 and $2.0 \mathrm{U}$ of $\mathrm{Ep} / \mathrm{ml}$; no significant increase in EC occurred with 2.5-6 U of Ep/ml (Fig. 2). The number of EC formed were directly proportional to the number of F-III cells $\left(0.5-3 \times 10^{6}\right.$ cells) plated in the presence of a constant concentration of $\mathrm{Ep}$ (Fig. 3).

When cells in F-I, -II, and -III were cultured separately, the number of EC formed at 14 days was inversely related to the number of monocytes present in each fraction (Table II).

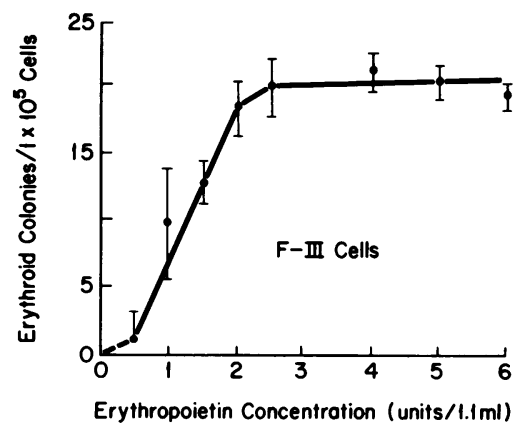

Figure 2 Effect of different doses of Ep on BFU-E-derived erythroid colony formation by monocyte-depleted (F-III) fraction of peripheral blood mononuclear cells in plasma clot cultures. Each point represents the mean $\pm \mathrm{SE}$ of six separate experiments. 


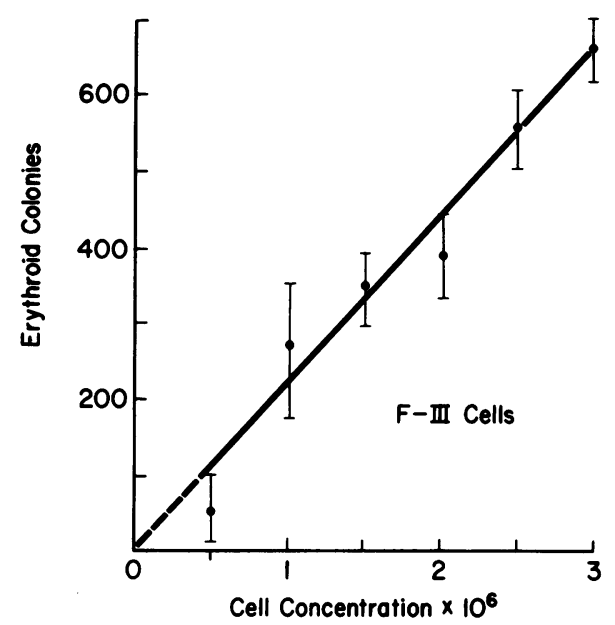

FIGURE 3 Effect of increasing concentrations of cells from monocyte-depleted (F-III) fraction of peripheral blood mononuclear cells on BFU-E-derived erythroid colony formation in the presence of $4 \mathrm{IU} \mathrm{Ep}$ in plasma clot cultures. Each point represents the mean $\pm S E$ of seven separate experiments.

The correlation coefficient between the percentage of monocytes $(0-15 \%)$ and the number of EC formed from $10^{5} \mathrm{~F}-\mathrm{I}$, -II, or -III cells was $0.96, P<0.001$. Essentially no EC were formed when $>20 \%$ monocytes were present (Fig. 4). To further examine the relationship between monocyte number and BFU-E proliferation, purified autologous monocytes (F-IV) were admixed with F-III cells to yield a constant final concentration of $2 \times 10^{6}$ cells $/ 1.1 \mathrm{ml}$ containing $0,5,15$, and 30\% monocytes (Table III). Under these conditions the number of EC formed was inversely proportional to the percentage of monocytes present. Because a con-

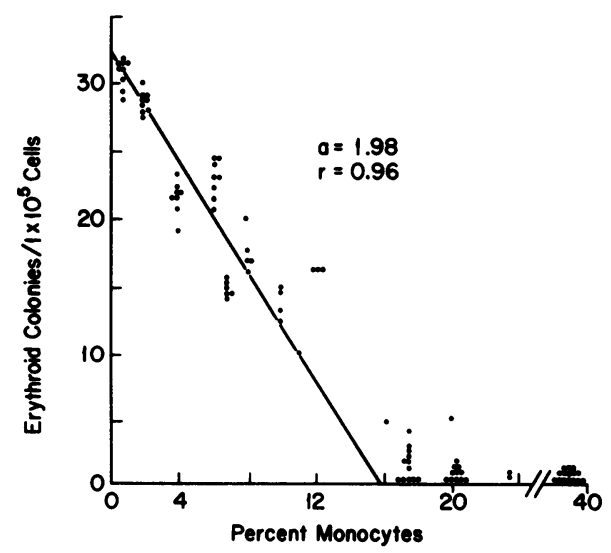

FIGURE 4 The relationship between BFU-E-derived erythroid colony formation and the percentage of monocytes present in peripheral blood mononuclear cells. Each dot represents a single experiment. The regression line was determined by the least square analysis of data obtained from cultures containing $0-15 \%$ monocytes.
TABLE III

Effect of Purified Monocytes (F-IV Cells) on Erythroid Colony Formation by Monocyte-Depleted Fraction (F-III Cells) of Peripheral Blood Mononuclear Cells in Plasma Clot Cultures

\begin{tabular}{cccc}
\hline & & \multicolumn{2}{c}{ No. of BFU-E/10s cells* } \\
\cline { 3 - 4 } No. of F-III cells & No. of F-IV cells & No Ep & +4 IU Ep \\
\hline $1.4 \times 10^{6}$ & 0 & 0 & $17.8 \pm 1.0$ \\
$1.4 \times 10^{6}$ & 600,000 & 0 & 0 \\
$1.7 \times 10^{6}$ & 0 & 0 & $21.4 \pm 1.3$ \\
$1.7 \times 10^{5}$ & 300,000 & 0 & $2.1 \pm 0.5$ \\
$1.9 \times 10^{6}$ & 0 & 0 & $22.9 \pm 1.5$ \\
$1.9 \times 10^{6}$ & 100,000 & 0 & $11.3 \pm 1.0$
\end{tabular}

* Each value represents the mean $\pm 1 \mathrm{SE}$ of eight separate studies. Values are based on numbers of F-III cells plated. Total number of cells (F-III and F-IV) was $2.0 \times 10^{6}$ cells $/ 1.1 \mathrm{ml}$.

stant number of cells per well were used in the previous experiments, the possibility existed that the reduction in EC was a result of dilution of BFU-E by monocytes. To examine this question, various numbers of autologous F-IV cells were co-cultured with a constant number of F-III cells (Table IV). The number of EC were reduced as increasing numbers of F-IV cells (95\% monocytes) were added. Thus the observed monocyte suppression of EC formation was not directly related to BFU-E dilution alone.

Because Ep is essential for normal BFU-E proliferation (no colonies were formed in the absence of $\mathrm{Ep}$ ), monocyte absorption or utilization of Ep could suppress EC formation. However, the experiments just

TABLE IV

Effect of Purified Monocytes (F-IV Cells) on Erythroid Colony Formation by Monocyte-Depleted Fraction (F-III Cells) of Peripheral Blood Mononuclear Cells in Plasma Clot Cultures

\begin{tabular}{cccc}
\hline & & \multicolumn{2}{c}{ No. of BFU-E $/ 10^{5}$ cells } \\
\cline { 3 - 4 } No. of F-III cells & No. of F-IV cells & No Ep & +4 IU Ep \\
\hline $2 \times 10^{6}$ & 0 & 0 & $24.6 \pm 2.1$ \\
$2 \times 10^{6}$ & 40,000 & 0 & $18.3 \pm 1.8$ \\
$2 \times 10^{6}$ & 80,000 & 0 & $12.9 \pm 2.3$ \\
$2 \times 10^{6}$ & 120,000 & 0 & $9.7 \pm 1.2$ \\
$2 \times 10^{6}$ & 200,000 & 0 & $5.1 \pm 0.8$ \\
$2 \times 10^{6}$ & 300,000 & 0 & $2.6 \pm 0.7$ \\
$2 \times 10^{6}$ & 480,000 & 0 & 0
\end{tabular}

* Each value represents the mean \pm 1 SE of six separate studies. Values are based on numbers of F-III cells plated. Total number of cells (F-III and F-IV) ranged from 2.04 to $2.48 \times 10^{6}$ cells $/ 1.1 \mathrm{ml}$ depending upon the number of monocytes added to cultures. 
described were performed with an excess of $\operatorname{Ep~(4~U/~}$ $\mathrm{ml}$ ), so monocyte utilization of $\mathrm{Ep}$ is unlikely. To further examine this possibility, $1-4 \times 10^{6}$ F-I cells were preincubated with culture media containing 1-4 U of $\mathrm{Ep} / \mathrm{ml}$ for 0.5 or $36 \mathrm{~h}$ at $37^{\circ} \mathrm{C}$. Media were then freed of cells by centrifugation and tested for Ep depletion. Preincubated media exhibited no reduction in Ep activity when measured in the exhypoxic polycythemic mouse (Table V). Therefore, it is most unlikely that monocytes suppress EC formation by decreasing the availability of Ep to BFU-E.

To determine if suppression of BFU-E was a nonspecific effect of the co-culture of heterologous cells, F-III cells were cultured alone, with $30 \%$ monocytes (F-IV), or $30 \%$ granulocytes; resultant BFU-E $/ 10^{5} \mathrm{~F}$ III cells were $29 \pm 14,1 \pm 0.5$, and $28 \pm 10$, respectively $(n=3)$.

The following experiment was performed to determine if monocyte suppression of BFU-E required direct cell-cell contact. Monocyte monolayers were prepared by adding various numbers of F-IV cells to microwells in $0.1 \mathrm{ml}$ of RPMI containing $20 \%$ autologous serum and permitted to adhere to the plastic for $1 \mathrm{~h}$. F-III cells $\left(2 \times 10^{5}\right)$ alone or with monocytes were plated in separate microwells in complete plasma medium and allowed to clot. The supernate was then removed from monocyte monolayers and the plasma clots containing

TABLE V

Effect of Peripheral Blood Mononuclear (PBM) Cells on Ep In Vitro*

\begin{tabular}{lll}
\hline & \multicolumn{2}{c}{ IRP equivalent units of Ep/culture $\$$} \\
\cline { 2 - 3 } No. of PBM $\$$ & In medium alone & Medium + PBM \\
\hline $1 \times 10^{6}$ & $1(13.6 \pm 1.3)^{4}$ & $1(14.8 \pm 2.1)$ \\
$1 \times 10^{6}$ & $2(19.4 \pm 1.9)$ & $2(17.9 \pm 2.3)$ \\
$1 \times 10^{6}$ & $4(16.2 \pm 1.7)$ & $4(16.5 \pm 0.8)$ \\
$2 \times 10^{6}$ & $1(8.2 \pm 0.9)$ & $1(9.3 \pm 1.0)$ \\
$2 \times 10^{6}$ & $2(12.7 \pm 1.1)$ & $2(15.8 \pm 2.9)$ \\
$2 \times 10^{6}$ & $4(15.3 \pm 2.0)$ & $4(14.7 \pm 1.6)$ \\
$4 \times 10^{6}$ & $1(11.2 \pm 1.2)$ & $1(13.6 \pm 1.4)$ \\
$4 \times 10^{6}$ & $2(9.9 \pm 0.5)$ & $2(11.3 \pm 1.7)$ \\
$4 \times 10^{6}$ & $4(19.8 \pm 1.8)$ & $4(19.0 \pm 2.0)$ \\
\hline
\end{tabular}

* Erythropoietin and different numbers of PBM were incubated together for $0.5 \mathrm{~h}$ ( 1 and $2 \times 10^{6}$ cells) or $36 \mathrm{~h}\left(4 \times 10^{6}\right.$ cells) at $37^{\circ} \mathrm{C}$ in a humidified atmosphere of $5 \% \mathrm{CO}_{2}$ in air; controls consisted of incubating the hormone in medium without PBM.

† PBM contained about $30 \%$ monocytes.

$\$$ Media were assayed in exhypoxic polycythemic mice and the percent erythrocytes- ${ }^{59} \mathrm{Fe}$ uptakes converted to equivalent units of Ep by reference to dose-response curve established for the International Reference Preparation (IRP) of Ep.

T The values in parentheses indicate the percent erythrocytes${ }^{59} \mathrm{Fe}$ uptake in assay mice induced by similar volumes of media from each category.
F-III cells and Ep were transferred by "flipping" onto monocyte monolayers or onto control wells (which had contained RPMI with $20 \%$ autologous serum alone). Thus, BFU-E proliferation was compared in clots containing (a) F-III cells, $(b)$ monocytes plus F-III cells, and $(c)$ in clots containing F-III cells that were placed over preformed monocyte monolayers. Monocytes suppressed BFU-E formation whether they were placed in or under clots containing F-III cells (Table VI).

Several investigators have reported that BFU-E present in interface fractions of isopycnic gradients proliferated without monocyte depletion of this fraction (15). To determine if standard centrifugation time (40 min) and temperature (room temperature) might partially deplete interface cells of monocytes and thus explain these apparently incongruous observations, the following experiment was performed. Blood was diluted as previously described, layered over FicollHypaque or commercially prepared Ficoll-Paque, and then centrifuged for $25 \mathrm{~min}$ at $15^{\circ} \mathrm{C}$ or for $40 \mathrm{~min}$ at room temperature $\left(25^{\circ} \mathrm{C}\right)$. Increasing the time and temperature reduced the number of monocytes present two- to fourfold (Table VII). The results in Table VII once again demonstrate a relationship between the number of BFU-E-derived colonies and the percent monocytes present in the cell preparation.

\section{DISCUSSION}

These data demonstrate that human monocytes suppress EC formation from peripheral blood BFU-E. The number of EC formed from peripheral blood mononuclear cells was inversely related to the number of monocytes present. Furthermore, addition of purified monocytes to monocyte-depleted mononuclear preparations inhibited EC formation.

Monocytes did not inhibit EC formation by utilization or absorption of EP because $(a)$ preincubation of

TABLE VI

Effect of Monocytes on Erythroid Colony Formation: Influence of Monocyte Proximity to F-III Cells

\begin{tabular}{ccc}
\hline Monocytes & $\begin{array}{c}\text { F-III + monocytes } ₫ \\
\text { (premixed) }\end{array}$ & $\begin{array}{c}\text { F-III cells + monocyte } \\
\text { (monolayer) }\end{array}$ \\
\hline$\%$ & & \\
0 & $23 \pm 10$ & $23 \pm 10$ \\
10 & $4 \pm 2$ & $15 \pm 6$ \\
20 & $0.5 \pm 0.5$ & $12 \pm 7$ \\
30 & $0.5 \pm 0.5$ & $3 \pm 2$ \\
\hline
\end{tabular}

$* 2 \times 10^{6}$ F-III cells and 4 IU Ep were used.

\$ Monocytes and F-III cells were admixed and cultured for 14 days. Numbers represent mean $\pm 1 \mathrm{SE}$ of three experiments. \$ F-III cells were added to wells in complete media and allowed to form clots before being transferred to other microwells containing monocyte monolayers. 
TABLE VII

Effect of Temperature, Time of Centrifugation, and Type of

Ficoll-Hypaque on Monocyte Content and BFU-E Proliferation in Separated Peripheral Blood Mononuclear Cells*

\begin{tabular}{cccc}
\hline Separation conditions & $\begin{array}{c}\text { Monocytes } \\
\text { (morphology) }\end{array}$ & $\begin{array}{c}\text { Monocytes } \\
\text { (Sudan black } \\
\text { positivity) }\end{array}$ & $\begin{array}{c}\text { No. of BFU. } \\
\text { E/10s cells }\end{array}$ \\
\hline Ficoll-Hypaque $§$ & $\%$ & $\%$ & \\
25 min, $15^{\circ} \mathrm{C}$ & $18 \pm 2$ & $22 \pm 1$ & $2 \pm 0.4$ \\
40 min, $25^{\circ} \mathrm{C}$ & $4 \pm 3$ & $7 \pm 2$ & $13 \pm 3$ \\
Ficoll-Paque & & & \\
25 min, $15^{\circ} \mathrm{C}$ & $16 \pm 3$ & $18 \pm 1$ & $2 \pm 0.5$ \\
40 min, $25^{\circ} \mathrm{C}$ & $6 \pm 1$ & $9 \pm 1$ & $8 \pm 2$ \\
\hline
\end{tabular}

* See text for explanation.

\# Each value represents the mean $\pm 1 \mathrm{SE}$ of three separate studies.

$\$$ Prepared in our laboratory with Hypaque purchased from Winthrop Laboratories, Sterling Drug Co., Inc.

I Ficoll-Paque was purchased from Pharmacia Fine Chemicals.

media containing Ep with F-I cells (30\% monocytes) did not reduce the quantity of Ep present as measured by the exhypoxic polycythemic mouse, and $(b)$ high concentrations of Ep did not reverse monocyte suppression of EC formation. It is unlikely that monocyte suppression of EC formation was a result of media depletion because $(a)$ only $10 \%$ monocytes significantly suppressed EC formation, and $(b)$ increasing the number of F-III cells cultured resulted in a linear increase in the number of BFU-E and (c) granulocytes did not inhibit BFU-E proliferation. The suppression of BFU-E by added purified autologous monocytes was not a result of the lidocaine employed in the recovery of monocytes because the addition of lidocaine-treated, bone marrow- or thymus-derived lymphocytes did not inhibit BFU-E proliferation. Moreover, the degree of observed BFU-E suppression was not related to whether endogenous or purified autologous monocytes were present in culture. In addition, functions of purified monocytes in F-IV and unfractionated monocytes in F-I were equivalent (14).

Several possibilities exist as to the mechanism by which monocytes affect erythropoiesis. It is possible that monocytes might dilute BFU-E and thus reduce the number plated. However, admixture of $4.8 \times 10^{5}$ monocytes and $2 \times 10^{6} \mathrm{~F}$-III cells resulted in the maximum BFU-E dilution of $30 \%$ and complete inhibition of EC formation (Table III). In contrast, a simple $30 \%$ reduction in the number of plated F-III cells resulted in only a $25-30 \%$ decrease in EC formation (Fig. 3). In addition, the observed suppression was also significant when the number of EC was expressed per $10^{5}$ F-III cells plated. Moreover, when the number of F-III cells plated was held constant in the presence of purified monocytes, suppression of EC formation occurred (Table IV). Monocytes may exert their effect by secreting substances capable of suppressing BFU-E. In this regard murine macrophages have been shown to secrete nontoxic chalones, cytotoxins, and prostaglandins that inhibit proliferation of a variety of nonerythroid cells $(16,17)$. However, when media conditioned by monocytes for 4-12 days were added to F-III cells, BFU-E proliferation and (or) differentiation was enhanced. This is in accord with recent observations that leukocyte-conditioned media stimulates CFU-E proliferation (18). However, these findings do not rule out the possibility that a short-lived secretory product with a local effect may mediate monocyte suppression of BFU-E proliferation. Finally, monocytes may mediate their effects by direct cell-cell contact. However, data presented in Table VI suggest that monocyte suppression of BFU-E may not involve cell-cell contact.

Three laboratories have previously reported BFU-E proliferation when blood mononuclear cells obtained by Ficoll-Hypaque gradients were cultured in the plasma-clot system $(10,15,19)$. These workers did not note the suppressive effects of monocytes on BFU-E that we have described here, and the number of viable monocytes in their cultured preparations were not reported. However, in the studies described here, efforts were made to preserve as many viable monocytes as possible in F-I. It should also be noted that a significant reduction in monocyte number occurs if blood is not used within $1 \mathrm{~h}$ of collection, when mononuclear cells are washed or allowed to stand in media containing divalent cations (monocyte-platelet clumping occurs), and when Ficoll-Hypaque gradients are centrifuged for longer than 25 min (Table VII). In this regard, Papayannapoulou et al. (15) employed mononuclear cells which had been at least partially depleted of monocytes by adherence to plastic dishes for $2 \mathrm{~h}$. Clarke and Housman (10) obtained 9.8-20 BFU-E $/ 10^{5}$ nucleated cells (mean, 15.6 ), or $110-200 / \mathrm{ml}$ blood. Similarly, Nathan et al. obtained 7-23 BFU-E/ $10^{5}$ cells (mean, 15.2) (19). It is of interest that $(a)$ this range of BFU-E resulted in our studies when cell preparations were contaminated with 6-12\% monocytes (Fig. 4) and that $(b)$ this cell monocyte distribution in Ficoll-Hypaque interface preparations is commonly reported when no special efforts are made to preserve monocyte number and is the same cell distribution we found in our preliminary studies. In contrast, when F-III cells containing $\leq 2 \%$ monocytes were cultured in the same system, 28-32 BFU-E $/ 10^{5}$ cells (mean, 29.5, Fig. 4), or $300-360 / \mathrm{ml}$ blood were observed. It is also important to note that when cultured cells from normal donors contained $\leq 2 \%$ monocytes (Fig. 4), minimal variation in the number of BFU-E $/ \mathrm{ml}$ blood or per $10^{5}$ nucleated cells occurred. Therefore, it is possible that the lower numbers and variability of BFU-E detected 
in other laboratories may be related to the presence of variable numbers of monocytes in cultures.

Several in vivo and in vitro observations have suggested that monocyte-macrophages may be involved in the regulation of hematopoiesis. Trentin (20), for example, described an erythroid hematopoietic inductive microenvironment that plays an important role in directing the differentiation of the multipotential stem cell or its progeny toward the erythroid line. A defect in the hematopoietic inductive microenvironment is considered to be responsible for the genetically determined anemia seen in Steel mice (21). Cells responsible for the hematopoietic inductive microenvironment are thought to be a type of reticulo-endothelial cell because they exhibit resistance to ionizing irradiation. The phenomenon of "hybrid resistance" or "CFU-E repression" described by Cudkowicz and Stimpfling (22) and McCulloch and Till (23) occurs in heavily irradiated animals, is not enhanced by immunization and is unlikely to involve B lymphocytes. Lotzova and Cudkowicz have implicated the macrophages in hybrid resistance, because treatment of the host with silica, a macrophage toxin, abrogated this phenomenon (24). A recent report by Aye suggests that monocyte-macrophages enhance the proliferation of human bone marrow CFU-E and BFU-E, because removal of adherent cell populations resulted in decreased bone marrow CFU-E and BFU-E activity (18).

These findings are not necessarily discordant with our observations. Bone marrow contains $<1 \%$ monocyte-macrophages, a concentration that did not inhibit BFU-E proliferation in these studies (25). We could not demonstrate monocyte enhancement of peripheral blood BFU-E proliferation at low monocyte concentrations $(<1 \%)$ or when F-III was cultured at suboptimal plating efficiency $\left(<0.5 \times 10^{5}\right.$ cells/culture $)$ with $1-5 \%$ monocytes. Nevertheless, this low concentration of monocyte-macrophages may be necessary for optimal bone marrow CFU-E and BFU-E proliferation. Also; if an intermediate suppressor cell is necessary for mediation of the monocyte effect, such a suppressor cell could be present in peripheral blood and absent in bone marrow. Finally, bone marrow and peripheral blood BFU-E may differ in their proliferative characteristics and susceptibility to inhibition by monocytes.

A number of clinical and laboratory observations suggest that monocyte suppression of EC formation in vitro may have in vivo significance. Infection and treatment of mice or rats with agents that enhance monopoiesis and activate macrophages, suppress erythropoiesis and enhance myelopoiesis $(26,27)$. Thus, increased bone marrow content and activity of monocytes and macrophages could enhance myelopoiesis by increasing, in situ, the concentration of colony stimulating factor. Concomitantly, BFU-E proliferation and eventually erythrocyte production may be reduced. In this regard, the transient or persistent anemias associated with infections and neoplasms in man may be related to the enhanced proliferation and activity of monocytes in these states $(28-31)$.

\section{ACKNOWLEDGMENTS}

This work was supported by grants CA-18755 and CA-23021 from the National Cancer Institute, National Institutes of Health, and by Veterans Administration Research Funds.

\section{REFERENCES}

1. Gordon, A. S. 1973. Erythropoietin. Vitam. Horm. 31: 105-174.

2. Zanjani, E. D., J. D. Lutton, R. Hoffman, and L. R. Wasserman. 1977. Erythroid colony formation by polycythemia vera bone marrow. In vitro dependence on erythropoietin. J. Clin. Invest. 59: 841-848.

3. Goodman, J. W., and S. G. Shinpock, 1969. Influence of thymus cells on erythropoiesis of parental marrow in irradiated hybrid mice. Proc. Soc. Exp. Biol. Med. 129: 417-422.

4. Wiktor-Jedrezejczak, W., S. Sharkis, A. Ahmed, K. W. Sell, and G. W. Santos. 1977. Theta-sensitive cell and erythropoiesis: identification of a defect in $\mathrm{W} / \mathrm{W}^{\mathrm{v}}$ anemic mice. Science (Wash. D. C.). 196: 313-315.

5. Petrov, R. V., R. M. Khaitov, N. V. Aleinikova, and L. V. Gulak. 1977. Factors controlling stem cell recirculation. III. Effect of the thymus on the migration and differentiation of hemopoietic stem cells. Blood. 49: 865-872.

6. Petrov, R. V., L. S. Seslavina, E. I. Pantelejev, and O. S. Yegorava. 1977. Inactivation of stem cells by lymphocytes nonlinked to the H-2 histocompatibility system. Transplant. Proc. 9: 555-557.

7. Hoffman, R., E. D. Zanjani, J. Vila, R. Zalusky, J. Lutton, and L. R. Wasserman. 1976. Diamond-Blackfan syndrome: lymphocyte-mediated suppression of erythropoiesis. Science (Wash. D. C.). 193: 899-900.

8. Hoffman, R., E. D. Zanjani, J. Lutton, R. Zalusky, and L. R. Wasserman. 1977. Suppression of erythroid-colony formation by lymphocytes from patients with aplastic anemia. N. Engl. J. Med. 296: 10-13.

9. Steinberg, M. H., M. F. Coleman, and J. B. Pennebaker. 1977. Diamond-Blackfan syndrome: T cell mediated suppression of erythropoiesis and serum blocking factor associated with complete remission. Blood. 50(Suppl. 1): 98. (Abstr.)

10. Clarke, B. J., and D. Housman. 1977. Characterization of an erythroid precursor cell of high proliferative capacity in normal human peripheral blood. Proc. Natl. Acad. Sci. U. S. A. 74: 1105-1109.

11. Boyum, A. 1968. Isolation of mononuclear cells and granulocytes from human blood. Scan. J. Clin. Lab. Invest. 21(Suppl. 97): 77-109.

12. Goldstein, K., H. D. Preisler, J. D. Lutton, and E. D. Zanjani. 1974. Erythroid colony formation in vitro by dimethylsulfoxide-treated erythroleukemic cells. Blood. 44: $831-838$.

13. Camiscoli, J. F., A. H. Weintraub, and A. S. Gordon. 1968. Comparative assay of erythropoietin standards. Ann. N. Y. Acad. Sci. 149: 40-45.

14. Rinehart, J. J., and M. E. Kaplan. 1978. A new method for isolation of human monocytes. J. Immunol. Methods. In press.

15. Papayannapoulou, T., M. Brice, and G. Stamatoyannopoulas. 1977. Hemoglobin F synthesis in vitro: evidence 
for control at the level of primitive erythroid stem cells. Proc. Natl. Acad. Sci. U. S. A. 74: 2923-2927.

16. Unanue, E. R., D. I. Beller, J. Calderon, J. M. Kielz, and M. J. Stadecker. 1976. Regulation of immunity and inflammation by mediators from macrophages. Am. J. Pathol. 85(2): 465-478.

17. Moore, M. A. S. 1976. Regulatory role of macrophages in hemopoiesis. J. Reticuloendothel Soc. 20(1): 89-91.

18. Aye, M. T. 1977. Erythroid colony formation in cultures of human marrow: effect of leukocyte conditioned medium. J. Cell Physiol. 91: 69-77.

19. Nathan, D., L. Chess, D. Hillman, B. Clarke, B. Allen, and D. Housman. 1977. Erythroid burst forming units (BFU-E) are null cells but their growth in vitro requires helper T-cells. Blood. 50: (Suppl. 1): 133.

20. Trentin, J. J. 1970. Influence of hematopoietic organ stroma (hematopoietic inductive microenvironment) on stem cell differentiation, regulation of hematopoiesis. A. S. Gordon, editor. Appleton-Century-Crofts, Inc., New York. 161-186.

21. Metcalf, D., and M. A. S. Moore, 1971. Haemopoietic cells. American Elsevier Publishing Co., Inc., New York.

22. Cudkowicz, G., and J. H. Stimpfling. 1964. Deficient growth of C57BL marrow cells transplanted in F1 hybrid mice. Association with the histocompatibility-2 locus. Immunology. 7: 291-306.
23. McCulloch, E. A., and J. E. Till. 1963. Repression of colony-forming ability of C57BL hematopoietic cells transplanted into nonisologous hosts. J. Cell. Comp. Physiol. 61: 301-305.

24. Lotzova, E., and G. Cudkowicz. 1974. Abrogation of resistance to bone marrow grafts by silica particles. Prevention of the silica effect by the macrophage stabilizer poly-2-vinyl pyridine N-oxide. J. Immunol. 113: 798-803.

25. Wintrobe, M. 1974. Clinical Hematology. Lea \& Febiger, Philadelphia, 7th Edition (1976).

26. Van Furth, R., M. Diesselhoff-Den Dulk, and H. Mattie. 1973. Quantitative study on the production and kinetics of mononuclear phagocytes during acute inflammatory reaction. J. Exp. Med. 138: 1314-1330.

27. Haurani, F. I., and A. Meyer. 1976. Iron and the reticuloendothelial system. Adv. Exp. Med. Biol. 73: 171-187.

28. Meuret, G., and G. Hoffman. 1973. Monocyte kinetic studies in normal and disease states. Br. J. Haematol. 24: 275-285.

29. Charney, E., and G. Miller. 1964. Reticulocytopenia in sickle cell disease. Am. J. Dis. Child. 107: 450-455.

30. Owren, P. A. 1948. Congenital hemolytic jaundice: the pathogenesis of "hemolytic crises." Blood. 3: 231-248.

31. Lobuglio, A. F., and J. J. Rinehart. 1970. In vitro and in vivo modification of human macrophage receptor for IgG globulin. Clin. Res. 18: 409. 